Article

\title{
Gender Equality and UN Sustainable Development Goals: Priorities and Correlations in the Top Business Schools' Communication and Legitimation Strategies
}

\author{
Giorgia Miotto *(D), Marc Polo López and Josep Rom Rodríguez \\ Blanquerna School of Communication and International Relations, Ramon Llull University, Plaça Joan \\ Coromines, 08001 Barcelona, Spain; marcospl@blanquerna.url.edu (M.P.L.); joseprr@blanquerna.url.edu (J.R.R.) \\ * Correspondence: giorgiam@blanquerna.url.edu; Tel.: +0034-627212701
}

Received: 13 November 2018; Accepted: 1 January 2019; Published: 9 January 2019

check for updates

\begin{abstract}
Gender equality is still an issue in business schools, since women in MBAs classrooms, in faculty and in management teams have low representation. Challenges caused by lack of financial aids, salaries gap and a very masculine model avoid a better gender balance in the business graduate schools, which, globally, should lead women personal and professional development. The main objective of this research is to analyse business schools communication priorities related to gender equality projects and policies in their sustainability reports, considering these as a fundamental tool for corporate legitimacy. Through a content analysis of the sustainable reports of the top 50 business schools of the world, we elaborate a "Codes Frequency Report" focusing on "Goal 4: quality of education" (in relation with scholarships and grants allocation) and "Goal 5: gender equality" and we explore the correlations with the schools' ranking positions, the price of the MBA programmes, the percentage of female MBA students, of female faculty members and women in board of directors in the different geographical areas as Europe, US and Asia. Results show that gender equality related topics are a source of positive impact and legitimacy for top business schools.
\end{abstract}

Keywords: gender equality; sustainable reports; business schools; higher education; legitimacy; UN SDGs; MBA

\section{Introduction}

Recently, the World Economic Forum published the Global Gender Report 2017, stating that, despite the fact that women represent half of the world's population, they do not have access to the same level of health assistance, education, economic participation, potential earning and political decision making power [1,2]. Worldwide, the "Economic Participation and Opportunity gap" has been closed just up to the $58 \%$, stressing the great differences that gender still makes in the potential achievement of wealth and happiness [2].

Gender equality and access to high quality education are main concerns for the global sustainable development. The United Nations highlighted these two items as a priority in the "2030 Sustainable Agenda" [3].

Education is a key factor to close this gap and graduate schools of business are in a privileged position to lead this change. These institutions are responsible, not only to train the future world's leaders but also to accelerate the gender gap closing, fostering women inclusion in their programmes classrooms, designing gender-inclusive leadership models and providing equal career opportunities $[2,4,5]$.

Working to close the gender gap is a great opportunity for actively collaborate with the "2030 Sustainable Agenda" and, therefore, for business schools' legitimation.

The main objective of this article is to analyse the priority that business schools (BS) address to gender equality and high quality education accessibility related topics in their communication strategy. 
The article is organised as follow: in the introduction we define a theoretical framework about responsible and sustainable development in the BS industry, we describe the gender equality issue in higher education, mainly related to the MBA programmes and we analyse the importance of sustainable reports (SR) as communication tools for legitimation.

In the "Material and Method" session, we describe the research methodology based in content analysis.

Afterword, we report the research results and discussions.

Finally, we set some conclusions and future research developments.

\subsection{Business Schools and Legitimacy}

In recent years, all business sectors have experienced the need to redefine their relationships with the society in terms of sustainability and added value, not only from the point of view of pure economic benefit $[6,7]$.

The enormous amount of information available in internet and the ease of access are changing the relationship between companies and society. This high degree of exposure converts organizations legitimacy difficult to acquire and to maintain over the time [8,9].

Company legitimacy derives from the recognition of its positive impact and is very important for the survival of organizations, because it ensures the flow of necessary resources to feed their activities [9-16].

According with institutional theory, an organization acquires legitimacy when it operates in an appropriate, desirable and acceptable manner for the social system $[17,18]$. Therefore, it achieves the social acceptance, because it conforms with the values, rules and meanings of the system [12,13].

Companies have responded to this demand for legitimacy by implementing strategies and policies related to the responsible and sustainable development [16,19-21].

Higher education institutions are leading this trend, training the future managers to be economically, environmentally and socially responsible and sustainable in their decision making process [22-26].

Specifically, BS reputation is affected by the current new and demanding stakeholders' mind-set [27]. These institutions, especially the most renown, are considered, in part, responsible for the financial worldwide crisis, since they trained the managers of several companies which were the protagonists of major financial scandals [12,26,28-30].

The society claims to BS a new positioning and commitment. They are asked to be an example of sustainable and responsible management and to be institutions focused on relevant knowledge production, delivery and transfer [25,31]. Business educators are considered responsible, not only for providing students with opportunities to build business skills but also to help them to understand the powerful effects that business decisions and actions can have on society and the potential collateral damage they can cause [32,33]. They are responsible to train the managers of the most important worldwide corporations which, most of the time, have more power than governments, because "public issues that once were covered by nation-state governance now fall under the discretion and responsibility of corporate managers" [34] (p. 903).

These organisations promote socially responsible and sustainable principles as a tool for redefining their relationship with the demanding corporate world and the society and for creating an added value for their stakeholders. This responsible and sustainable approach to research, training, managing, community outreach and knowledge transferring improve the higher education industry image and reputation $[22,26,27,30]$.

\subsection{Business Schools and Sustainability Reports}

Being responsible and sustainable today is not enough. It is necessary to share constantly with the stakeholders a coherent and consistent conversation [20,25,35], because "corporate moral legitimacy must be reproduced: by placing corporations into public communication network" [36] (p. 82). This public conversation is not intended to convince and manipulate stakeholders but to share information in an environment where transparency and accountability are mandatory [22,23,36-38]. 
$\mathrm{BS}$, as other industries, use SR as an instrument to set a dialogue and to engage a conversation with internal and external stakeholders and as a way to communicate their positive impact to the society $[27,38]$.

"'Sustainability Reporting' has established itself as a label for a new form of integrated reporting procedure dealing with economic, ecological and social performance. ... A sustainability report is a qualitative and quantitative information on the extent to which a corporation has managed to improve its economic, environmental and social effectiveness and efficiency in the reporting period and integrated these aspects into a sustainability management system" [37] (p. 76). Through SR organizations voluntary communicate their values and impacts, their progress in sustainable development, with the aim of building a stronger stakeholder engagement through transparency and accountability [38,39]. SR should measure and disclose to all stakeholders the organizational performance in term of sustainable development and performance [37,40].

In the higher education sector, SR are intended as a response for the stakeholders' accountability and transparency demand $[23,38,41]$ and they are a communication tool to legitimise their strategies and activities [23-25,42-46].

SR are also very useful as a source of information and tool for self-assessment for international rankings [47] and accreditations bodies [41,48]. In the BS rankings, the Financial Times includes criteria related to gender equality, diversity and meaningful research outputs for listing schools' positioning. International accreditation organizations as EFMD and AACSB have recently embraced new evaluation standards based on "Ethics, Responsibility and Sustainability" [49] and "Commitment to Corporate and Social Responsibility" requiring that: "The school must demonstrate a commitment to address, engage and respond to current and emerging corporate social responsibility issues (e.g., diversity, sustainable development, environmental sustainability and globalization of economic activity across cultures) through its policies, procedures, curricula, research, and/or outreach activities" [50] (p. 7). Collecting information and designing every year a SR is an useful exercise to assess the organization progress in terms of sustainability and social responsibility [51]. In these terms, SR could become a dynamic tool for sustainability development in the higher education industry [41].

In recent years, several authors have analysed the progress of sustainability through the $\mathrm{SR}^{\prime}$ content analysis [44,52-61] and most of them connect the use of SR with the legitimation process $[52-56,58,61]$. Nevertheless, there is still a gap in the research field related to SR in higher education $[23,38,39]$.

\subsection{Business Schools and Gender Equality}

The most relevant framework for BS sustainable and responsible strategies is, with no doubt, the one defined by the United Nations, through two organizations which work side by side with corporations and academic institutions worldwide: the Global Compact and the Principle for Responsible Management Education (PRME) [62-67].

One of the issues addressed by BS in their social narrative is gender equality in business administration. According to figures reported by the Financial Times, only four in 10 applicants on two-year, full-time MBAs (the business schools' flagship programme) in 2017 were women, even if in the US and in Europe there are more female graduate with an university degree [2,5]. Since 1962, when Harvard Business School allowed women to participate to the MBA programme, the percentage of female students have been substantially improving. Nevertheless, in 2016 only the $38 \%$ of globally MBA graduates were women [2]. Women valuate very positively business administration programmes [2] but quite often they decide to do not attend one of them. The main reason for women for not attending an MBA is the financial concern $[2,68,69]$, caused mainly by the difficulty of finding the necessary economic resource to pay the tuitions and living expenses [2]. In fact, women's salary between the university graduation and the MBA is lower than their male colleagues and obtaining funds for graduate school is a top challenge for them [5].

On top of this, the lack of female students in the business schools' flagship programme is accompanied by a further gap in salaries after the graduation and a slower career progression $[70,71]$. 
Only the $4.8 \%$ of Fortune 500 CEOs are women, 24 in total [72]. These aspect makes the MBA enrolment even less attractive for women [68].

Finally, the low rate of female faculty member and the prominent "male culture" increase the perception that business schools do not welcome female students as much as the male ones [68,73-75], creating a "gender fatigue" [75] to the point that some authors are claiming for a "femininization" of some aspects of the programmes curricula or BS management practices [76,77].

The main objective of this research is to analyse the priority that business schools acknowledge to gender equality related topics in their communication strategy and, therefore, the relationship between these topics, their sustainable strategies and legitimacy quest.

We consider that gender equality is a very relevant and sensitive topic and it is very important to inform the society about the changes that the most influent education institutions of the world are promoting in order to foster egalitarianism in higher education and, therefore, in management positions accessibility.

A gap in the research agenda about the management education industry's communication strategies related to gender equality have been noticed and addressed by this article. Actually, "Gender differences in the workplace are an ethical issue and the discursive constructions of gender management constitute a main stream of research in business ethics" [78] (p. 357).

However, we will not evaluate if the mentioned projects in the SR have been really implemented in each BS. This article is not an auditing work nor an "assurance of information" [16,79]. It is an analysis of the BS communication and legitimation strategies.

While we are aware of the need of deeply analyse if really BS "walk the talk" and promote gender equality just for marketing and accreditation reasons or they really engage in a long-term strategy to foster global sustainable development, at this stage of the research we focus on their communication strategies and legitimacy quest.

In the future, this research project will embrace a deeper and more assessing approach to the relationship between communication/reporting, gender equality, rankings and legitimacy in BS.

\section{Materials and Methods}

The focus of interest of this paper is in the area of sustainability reporting and communication. The main objective of this research is to explore how the best business schools of the world use gender equality related projects as a tool for legitimation in their sustainability reports.

The topic has been approached performing a content analysis of the Sustainability Reports of the top 50 business schools worldwide according to the "Financial Times Global MBA Ranking 2016" using as code of analysis the United Nations "17 Sustainable Development Goals" (SDGs) published by United Nations on 27 September 2015 and a comparative exploration with the gender related criteria of the ranking.

The 17 SDGs are the roadmap that United Nations included into the "2030 Sustainable Agenda" and the centre of the global political agenda to achieve the support of all organizations and individuals in order to create a more just, responsible and sustainable world $[3,64,80]$. The SDGs are based on values for human rights respect, justice, health and well-being for all the population, in an environmentally safe planet $[3,81]$. These goals, organised in 169 indicators, are meant to eradicate extreme poverty, provide universal quality education and medical assistance, fight against gender inequality, promote sustainable production and consumption and protect the environment [3].

In order to identify business schools' communication priorities and strategies related to gender equality, we elaborate a "Codes Frequency Report" focusing on "Goal 4: quality of education" (in relation with scholarships and grants allocation) and "Goal 5: gender equality" and we correlate it with items linked to each business school 's gender balance strategy ranked by the Financial Times.

The analysed documents have different formats, length and content and they were retrieved in the business schools' websites or PRME and Global Compact repositories. 
We chose the "Global MBA Ranking 2016" published by the Financial Times, considering the great importance of rankings in the BS industry [82-85], since they are not just the certification of the quality and prestige of a BS but also one of the most important source of legitimacy from the students, candidates, companies and alumni point of view [83,85-87]. The "Financial Times Global MBA Ranking" is the most influent ranking since it is the most well-known and geographically comprehensive $[85,88]$. For the sample selection we got inspired by the annual "KPMG International survey of corporate responsibility" which evaluates the G250 companies of the "2014 Fortune Global 500 Ranking" [53] and the research supported by the "Centre for Business Ethics, Bentley College" and the "Ethics Resource Centre" about the MBA curricula of the top 50 business schools according to the "Financial Times Global MBA Ranking 2006" [88]. To perform the content analysis and to manage more systematically the great quantity of data, we used the CADQAS software Atlas.ti [89-93].

Due to technical limitations of the software and to ensure a high level of homogenization of the Primary Documents (in Atlas.ti "Primary Documents" stands for each Sustainability Report), we only analysed the reports which we could retrieve as downloadable format in pdf [92,94,95], 30 in total $(n=30)$. We could not analyse the communication strategies of the BS which did not collect the information on a document or publish a report, since the Atlas.ti software does not allow the content analysis of websites and social networks.

The first step of the content analysis was encoding all the SR. Text encoding is necessary to reduce the large number of words included in the analysed documents in a much smaller number of categories those could be manage much more easily for the semantic analysis of the content and its classification $[95,96]$. The framework used for encoding the SR' content is based on the "17 Sustainable Development Goals" (SDGs) published by United Nations on 27 September 2015 [3,27,64]. The SDGs are a very important code of analysis to understand the alignment and communication priorities of the BS just after the "UN 2030 Sustainable Agenda" publication [97]. Each text's quote could be assigned to more than one SDG, because the mentioned topic could refer to different goals or indicators.

The effect or result variable used is the number of times which the BS mention, directly or indirectly, in their SR, a concept related to one or more SDGs. These results are collected in a "Codes Frequency Report".

Afterward, we focused on the topics related to gender equality: "Goal 5: gender equality". Considering the previously designed theoretical framework, the main causes for gender unbalance in business schools are: financial inaccessibility, lack of female leadership models and high cost of opportunity considering gender gap salary $[2,4,69,76,98]$. Therefore, in order to identify business schools' communication priorities and strategies related to gender equality, we analysed the correlation between these variables:

- "Goal 4: quality of education" (number of citations related to scholarships and grants allocation in the SR)

- $\quad$ "Goal 5: gender equality" (number of citations about projects and topics related to gender equality in the SR),

- $\quad$ the schools' ranking position, retrieved from the 2016 FT Ranking [99]

- $\quad$ the price of the MBA programmes retrieved from the 2016 FT Ranking [68]

- the percentage of female MBAs students retrieved from the 2016 FT Ranking (2\% of FT Ranking weight) [99]

- $\quad$ the percentage of female faculty members retrieved from the 2016 FT Ranking (2\% of FT Ranking weight) [99]

- $\quad$ the percentage of women in board of directors retrieved from the 2016 FT Ranking (1\% of FT Ranking weight) $[68,73-75,99]$.

- $\quad$ Europe is region 1, US is region 2 and Asia is region 3.

As Morley says in a very interesting article about women in the higher education industry: "We are aware that gender cannot be reduced to number and that it is a verb as well as a noun that is, 
we do gender via everyday transactions and relationships. Gender equality is not just about increasing quantitative representation." [100] (p. 801), nevertheless we needed objective variables in order to scale and analyse the issue.

The relationship tests and the variance associations applied in the research are nonparametric, since this approach is more suitable and robust for limited cases number research and counting scales [101].

We used Spearman rank correlations for correlations analysis [102]. Even if we are aware of the danger of endogeneity, we considered all the variables as dependent variables since the aim of the research was exactly identify and analyse possible correlations between all the set variables. In the "Results and discussion" part of the article we carefully propose some findings, taking into consideration the correlations between the variables and the theoretical framework.

We took into consideration the overall results and the peculiarities in the different geographical areas as Europe, US and Asia, since regional idiosyncrasies are a gap in the research agenda which we meant to fulfil as identified by Pettigrew and Starkey in the special issue "The Legitimacy and Impact of Business Schools: Key Issues and a Research Agenda" [65].

Table 1 show the collected data for the research.

Table 1. Collected data.

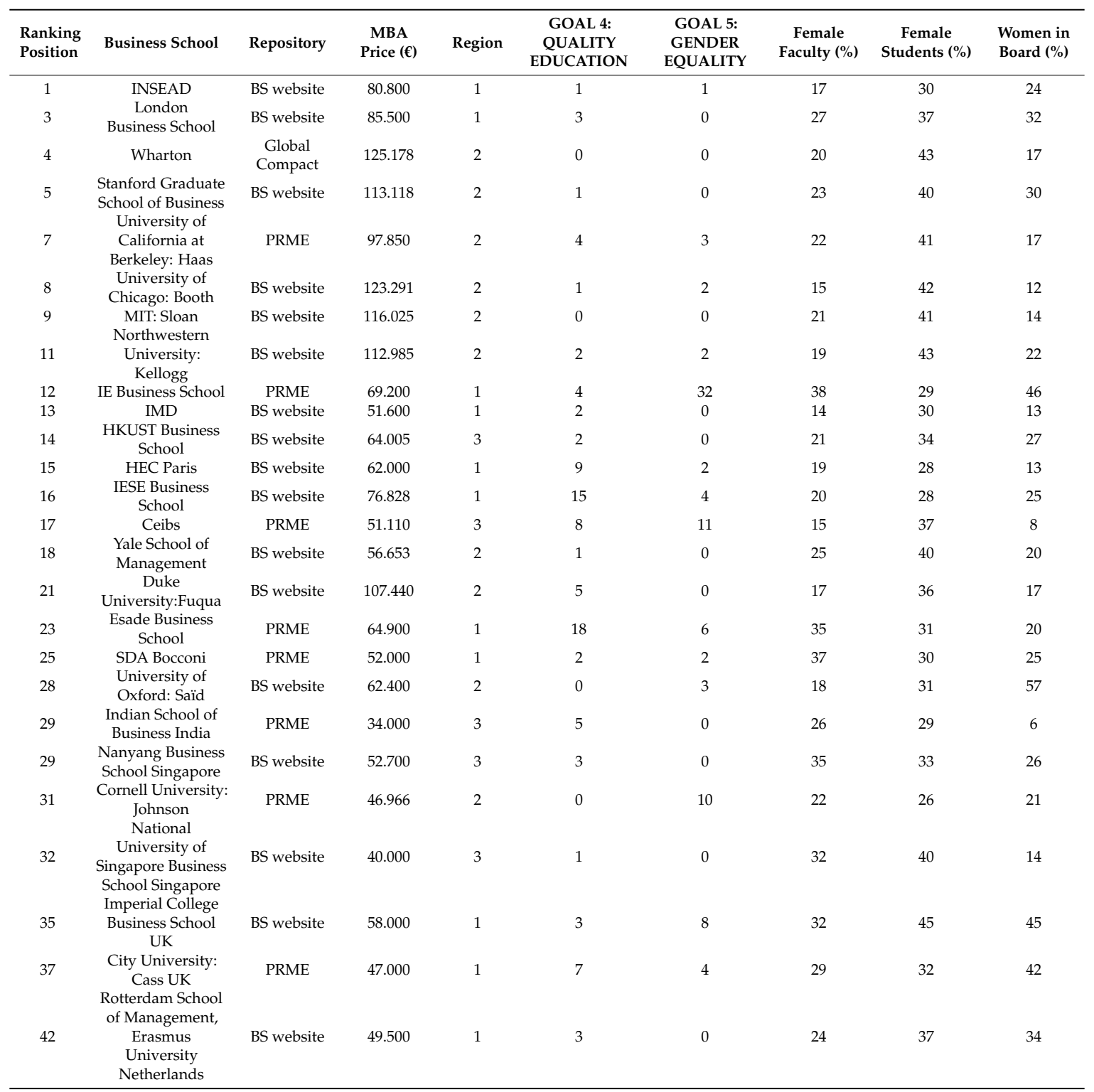


Table 1. Cont

\begin{tabular}{|c|c|c|c|c|c|c|c|c|c|}
\hline $\begin{array}{l}\text { Ranking } \\
\text { Position }\end{array}$ & Business School & Repository & $\begin{array}{c}\text { MBA } \\
\text { Price }(€)\end{array}$ & Region & $\begin{array}{c}\text { GOAL 4: } \\
\text { QUALITY } \\
\text { EDUCATION }\end{array}$ & $\begin{array}{c}\text { GOAL 5: } \\
\text { GENDER } \\
\text { EQUALITY }\end{array}$ & $\begin{array}{c}\text { Female } \\
\text { Faculty (\%) }\end{array}$ & $\begin{array}{c}\text { Female } \\
\text { Students (\%) }\end{array}$ & $\begin{array}{l}\text { Women in } \\
\text { Board (\%) }\end{array}$ \\
\hline 46 & $\begin{array}{l}\text { University of Texas } \\
\text { at Austin: } \\
\text { McCombs US }\end{array}$ & BS website & 44.033 & 2 & 0 & 0 & 26 & 32 & 10 \\
\hline 47 & $\begin{array}{c}\text { Fudan University } \\
\text { School of } \\
\text { Management } \\
\text { China }\end{array}$ & BS website & 38.000 & 3 & 1 & 7 & 34 & 51 & 4 \\
\hline 49 & $\begin{array}{c}\text { Mannheim } \\
\text { Business School }\end{array}$ & BS website & 39.000 & 1 & 0 & 0 & 27 & 40 & 20 \\
\hline
\end{tabular}

Source: authors elaboration.

\section{Results and Discussion}

This section reports the results of the comparative exploration based on a content analysis.

This is a synchronic, qualitative and interpretative semantic content analysis based on text coding [95, 96].

We organized the results presentation in four sections: first section is about the overall results, second section refers to European BS, the third to US BS and the forth to Asian institutions.

\subsection{Overall Results}

Figure 1 shows the average of citations in the SR about projects related to Goal 4 and Goal 5 in each BS in the three geographical areas.

The results show that there are differences in the use of gender equality as main topic in the sustainability narrative in the different business schools' SR.

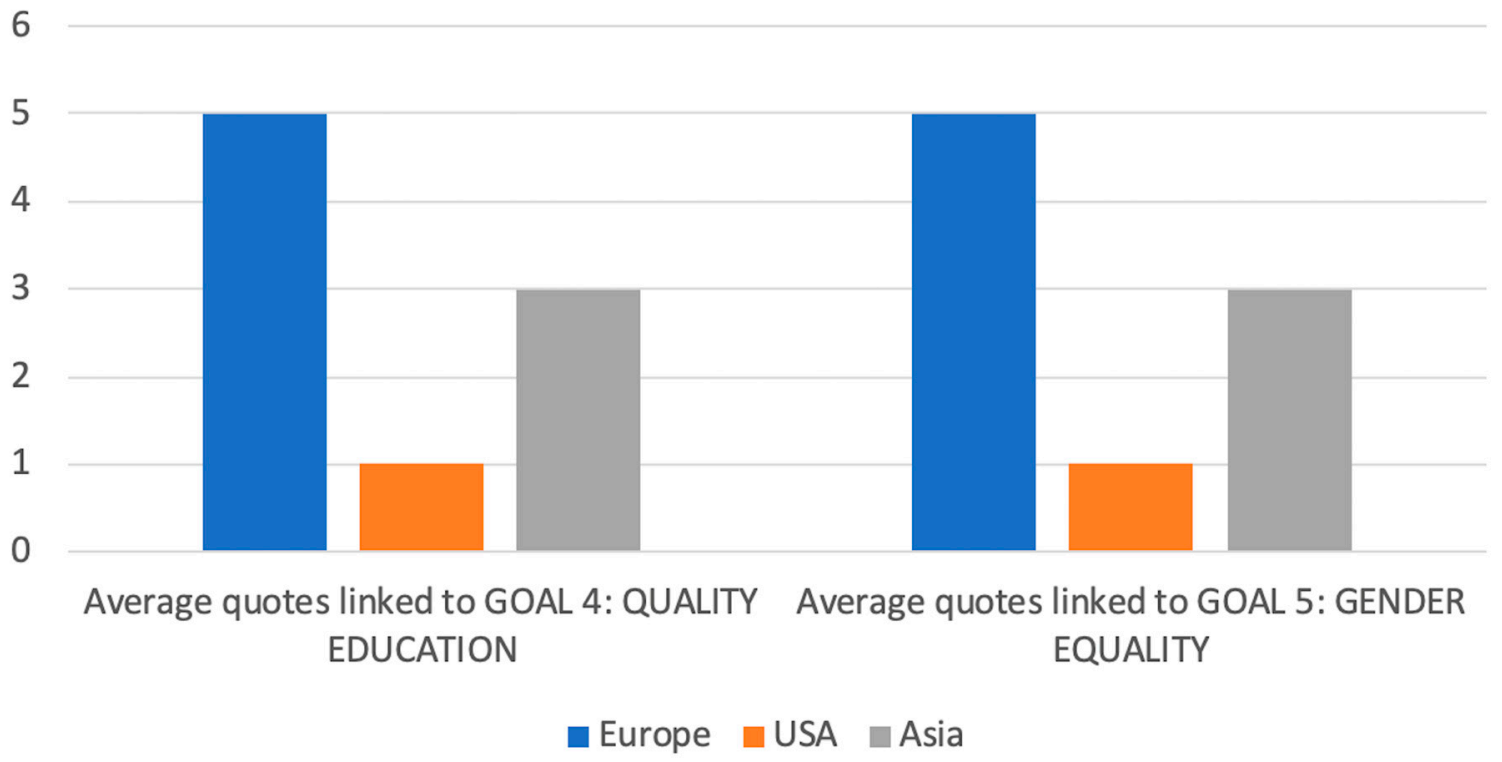

Figure 1. SDG 4 and SDG 5 related citations in the SR narrative.

European BS are the most focused on this topic, followed by the Asian. US BS do not consider gender equality an important issue to mentioned in their communication strategy, at least at SR level. IESE Business School from Spain is the institution more focused on gender equality projects. The same regional pattern applies to projects related to scholarships and financial accessibility (SDG 4). ESADE, from Spain, is the school that shows more concern for this topic in its sustainable narrative. 
Figure 2 shows the differences in the three geographical areas in the percentage of women in MBA classrooms, faculty members and directors reported by the "FT Global MBA Ranking 2016" [99]. The numbers indicate the percentages of women versus men.

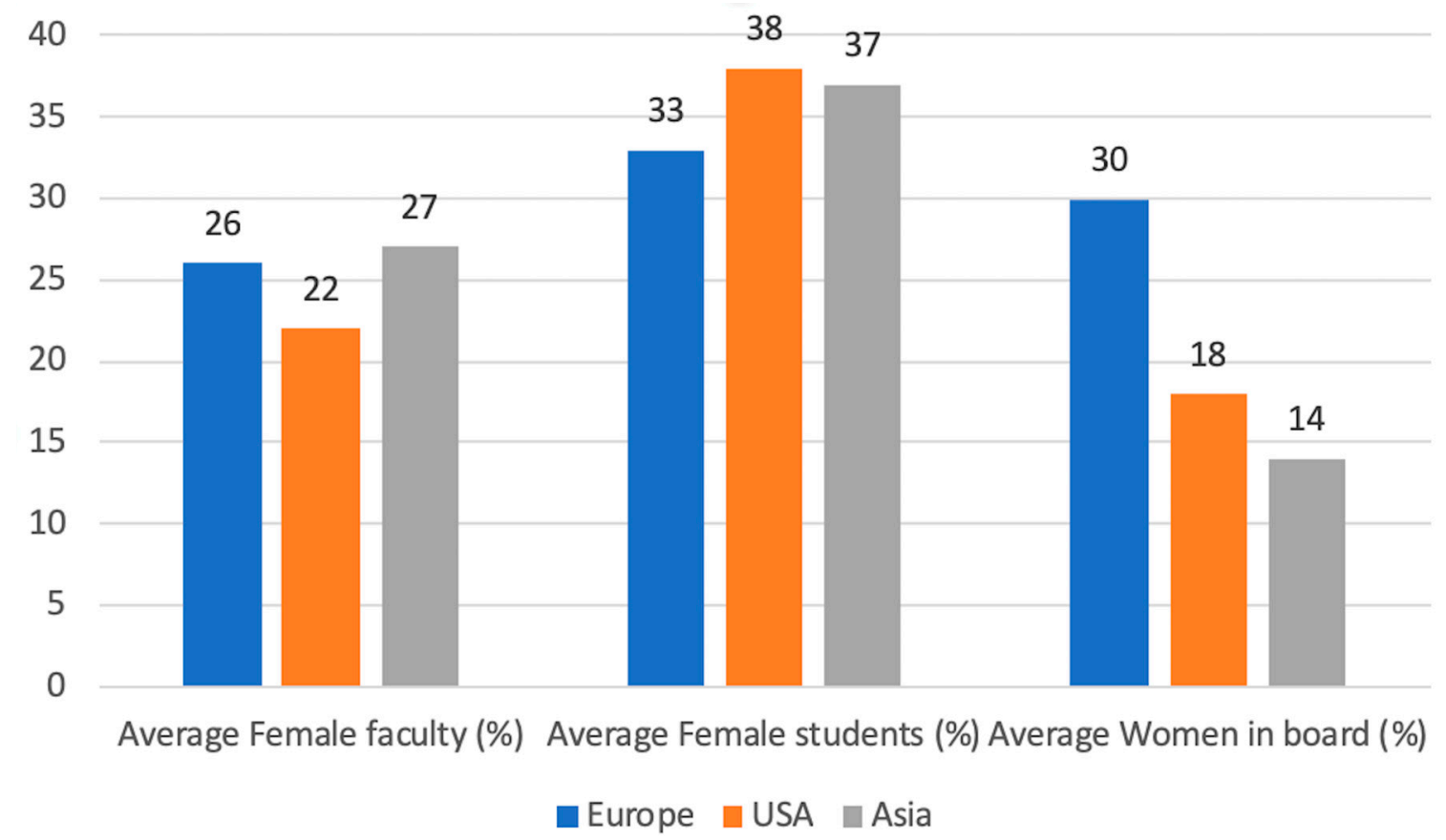

Figure 2. Gender balance in business school faculties, students and executive boards.

Results show that there is no stable correlation between the three considered variables. In each geographical area the relationship between the female presence in the faculty, MBA classrooms and board of directors is different.

Considering the 30 analysed BS, Asian best ranked institutions show averagely the higher number of women in their faculty. BS from China (Fudan University School of Management China) and Singapore (Nanyang Business School Singapore and National University of Singapore Business School Singapore) stand out with up to $35 \%$ of women in their core faculty. Also, IE Business Schools (38\%) and SDA Bocconi in Italy (35\%) show a high number of women in their faculty. On the contrary, the teaching and researching personnel of the University of Chicago Booth and CEIBS are the less gender balanced.

The recent economic growth, the resulting enlargement of the middle class and globalization increased the need of a new and more sophisticated higher education system in Asia. In these countries, good education means realistic options for a better life style, providing citizens with higher incomes and more fulfilling work [100]. Asian business schools are increasingly seeking for better results in rankings and reputation. Therefore they are trying to attract international faculty members from all around the world [103]. The faculty internationalization implies a higher number of female faculty which is slowly changing the traditional absence of women in Asian higher education institutions.

US business schools stand out for the average of women in MBA' classrooms. Northwestern University Kellogg and Wharton are the better balanced in the US, with the $43 \%$ of female students, won just by Fudan University School of Management China (51\%) and Imperial College Business School UK (45\%).

In the last ten years, several Asian countries developed projects in order to increase the number of female students in higher education and the business schools industry have worked to balance the very scarce presence of women in their classrooms [100].

Finally, considering the analysed institutions, European BS are the ones that welcome more women in their management teams. The $30 \%$ average of European BS executive boards members are 
female, versus $18 \%$ in the US and $14 \%$ in Asia. University of Oxford Saïd stands out with the $57 \%$ of female executive board members and Indian School of Business India and Fudan University School of Management China with a very low percentage ( $6 \%$ and $4 \%)$.

Even if the Directive 2014/95/EU about non-financial information disclosure, which obliges organizations to publish data about their environmental and social impact, included the gender balance in boards of directors and salaries, just applies to big listed companies [104], also European business schools are influenced by this new trend. Convinced that legitimacy improves financial performance thanks to an easier access to resources $[15,105]$ and aware that legitimacy depends on stakeholders support [11,19], European business schools embraced changes in corporate governance [106] such us increasing gender balance in the higher management and they communicate it as an example of responsible leadership and ethical decision making process.

Figure 3 presents the overall results of correlations between the different variables.

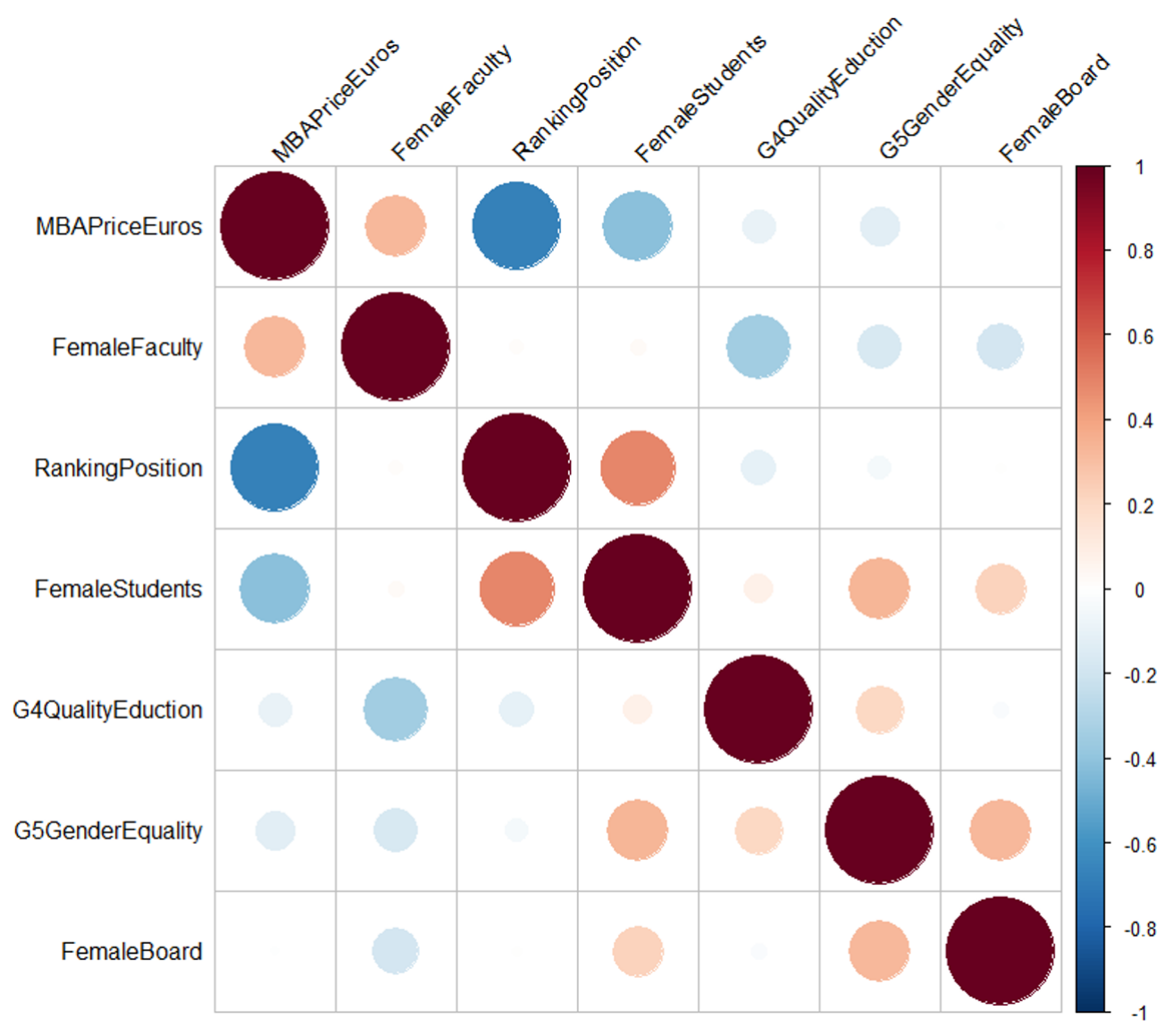

Figure 3. Overall results and correlations.

First of all, the overall results show a positive correlation between the priorities in the SR narrative related to "Goal 5: gender equality" and "Goal 4: quality of education". BS who consider gender equality important in their communication strategy also consider that scholarships and financial aids are a tool for stakeholders' engagement and legitimation. Women in BS and programmes affordability are confirmed to be very much linked topics as pointed out in the literature review $[1,2,5,68]$.

BS with a higher percentage of women in their executive boards are the ones more concerned about gender equality in their SR. Avoiding endogeneity, we are aware that we cannot establish a cause-effect correlation between these two variables, nevertheless we may positively assume that this relationship could demonstrate that women in leadership positions acknowledges an higher value to gender egalitarianism in the BS narratives, trying to foster gender diversity in higher business education [70,76,77]. In fact, as Carmona says: "presence of women in senior management 
roles may shape management discourses and practices" [78] (p. 2). Therefore, more women in the executive boards means a different management style and different priorities in the communication and legitimation strategy.

The BS with a higher percentage of female students in MBA programmes have a better ranking position, a higher number of women in their board and they focus their SR narrative in gender equality and programmes economic accessibility, even if the latest is less relevantly linked. Fostering women representation in the business administration classrooms is shown to be an argument for promoting sustainable development and BS reputation and legitimacy [1,2,4,22]. Actually, the number of female students impacts directly on ranking position, since this is a criteria set by the Financial Times [99].

Finally, MBAs' price and ranking position are not positively related to the gender equality priorities and relevance in the analysed BS. Top ranked elite BS do not stress more than the others their commitment to gender equality. Even if the Financial Times introduced three criteria related to women presence and participation in BS, these just sum $5 \%$ of the weight of the Ranking, versus the $40 \%$ linked to salary and salary increasing. Best BS in the world are still the ones those provide to their students a passport for the most brilliant career in term of economic results [107]. This pragmatic mindset still influences the BS reputation and legitimation strategy [107].

\subsection{European Business Schools Results}

Figure 4 presents the results of the correlations between the different variables in European Business Schools.

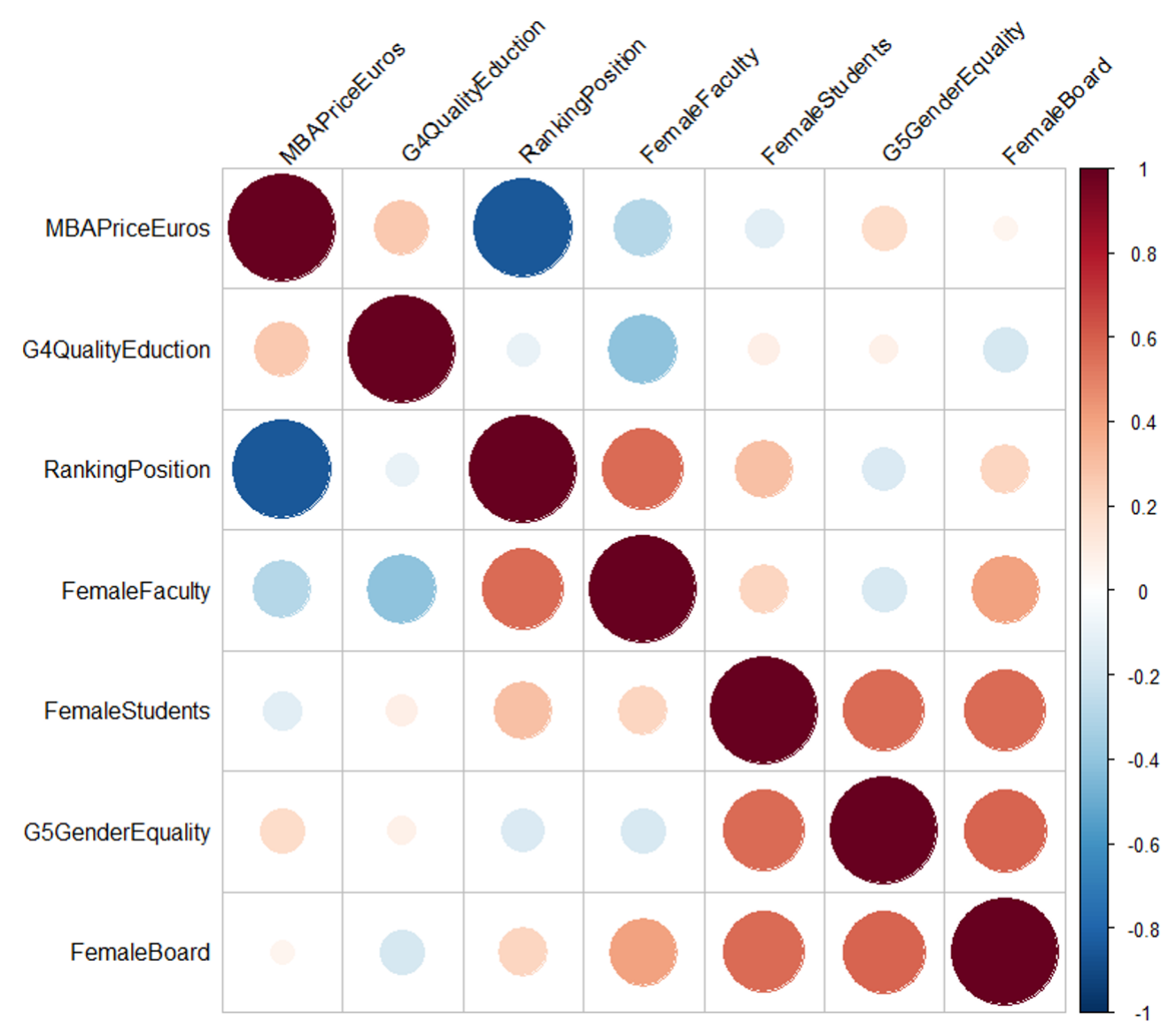

Figure 4. Results and correlations in European business schools.

According to these results, European BS which consider gender equality very relevant in their communication strategy are characterised by a major representation of women in the MBAs classrooms and in the schools' management teams. Nevertheless, this data is not related to the female faculty 
percentage, which still quite low, especially if we do not take into consideration ESADE, IESE and SDA Bocconi which really make a difference in the gender balance between the faculty members.

A higher percentage of women in the management team is positively linked with the number of female students and faculty members but this does not influence sensibly the focus on scholarships in the SR narrative. The theory that a female leadership model may improve gender equality in BS is confirmed in European institutions [4,76-78]. The EU focus on gender equality in executive boards and the recent agenda set on this topic in Europe definitely influence positively the women access on top management, even if we will need a lot of time in order to cover the gender gap caused by years of inequality and silence in this matter [104]. Nevertheless, cultural and economic issues are still a barrier for women to access to faculty positions.

At the other hand, providing financial funds through scholarships and awards, main concern that causes gender gap in business administration education [1,2,4], is not consider as a key message in the European BS communication strategies.

Finally, in European schools ranking position is related to female faculty members, female students and women in board of directors. This data confirms the small changing mind-set applied by the most important higher education ranking, in order to balance traditional quantitative financial standards as salary and economic career progress, introducing criteria linked with the sustainable development as gender and diversity in the BS industry [108] improves European BS positioning and performance against the well-established American institutions.

\subsection{US Business Schools Results}

Figure 5 shows results of the US business schools' analysis.

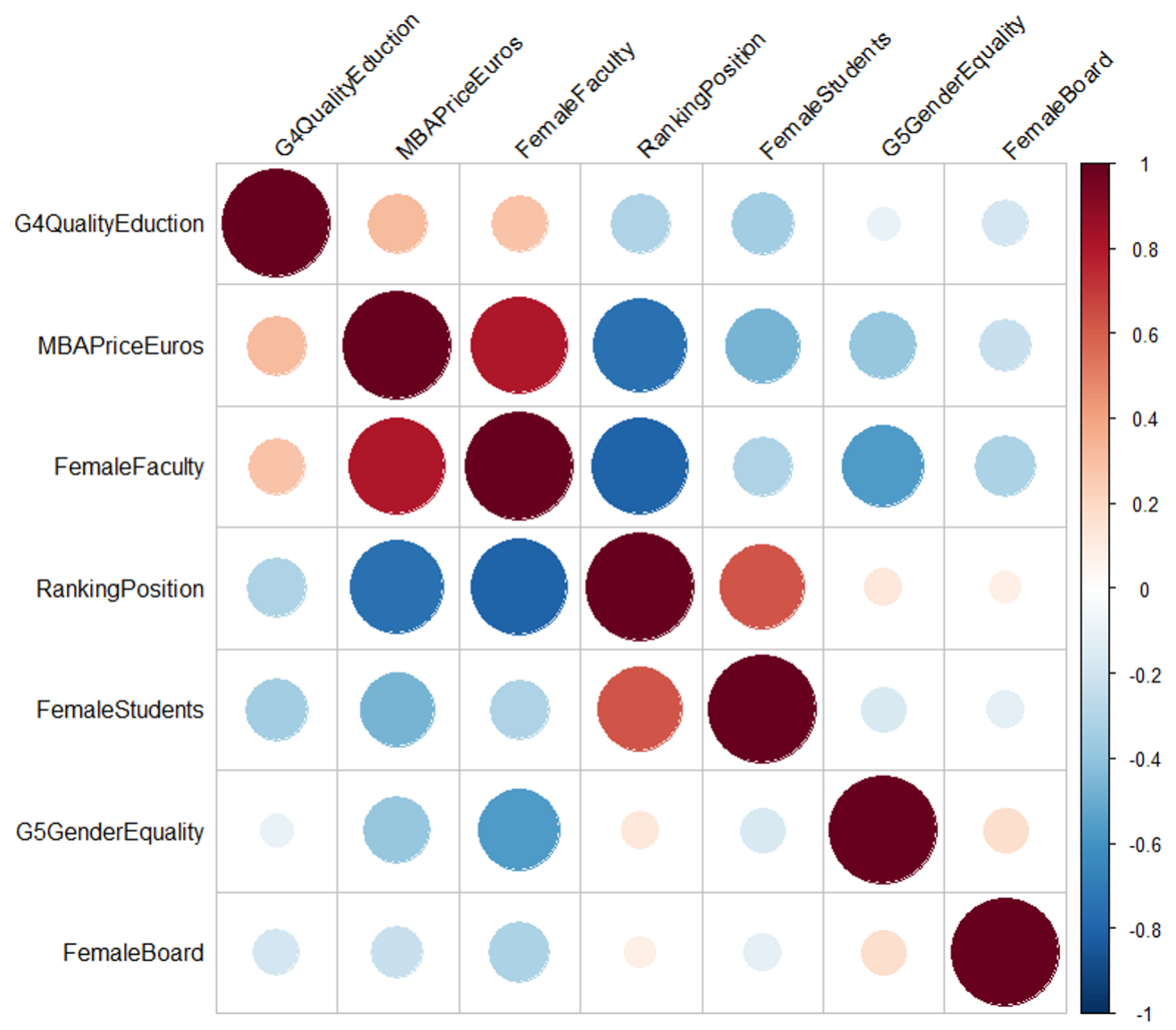

Figure 5. Results and correlations in US business schools. 
The most interesting correlation shows by the US business schools' analysis is the positive link between the MBA price and the percentage of female faculty, more expensive the programme, more women in the academic departments. Elite US BS make efforts to hire talented women in their faculty.

Besides that, we can notice a positive correlation between the MBA price and the priorities in communicating the available financial aids to attend the programmes. This could be a sign of self-awareness of the US BS about the economic challenge that women face when applying to their programmes. Actually, according to the last GMAC survey, the $38 \%$ of US business schools female applicants could not finally attend the programme because they could not find the way to fund it [1]. The classic merit-based financial aids policies are probably not enough to promote gender inclusion in the US BS, a new model of need-based scholarships programme need to be set $[1,4,69]$.

The US BS ranking positioning is slightly influenced by the percentage of female students, since the high weight of alumni salary is what really make the difference [107].

Gender equality projects and activities are not relevant in the SR narrative for the analysed US business schools and they are not positively linked with any other variables. Legitimacy strategy in US BS is still very much related to alumni performance, institutional networking and global development.

\subsection{Asian Business Schools Results}

Finally, Figure 6 presents the results for the Asian analysed business schools.

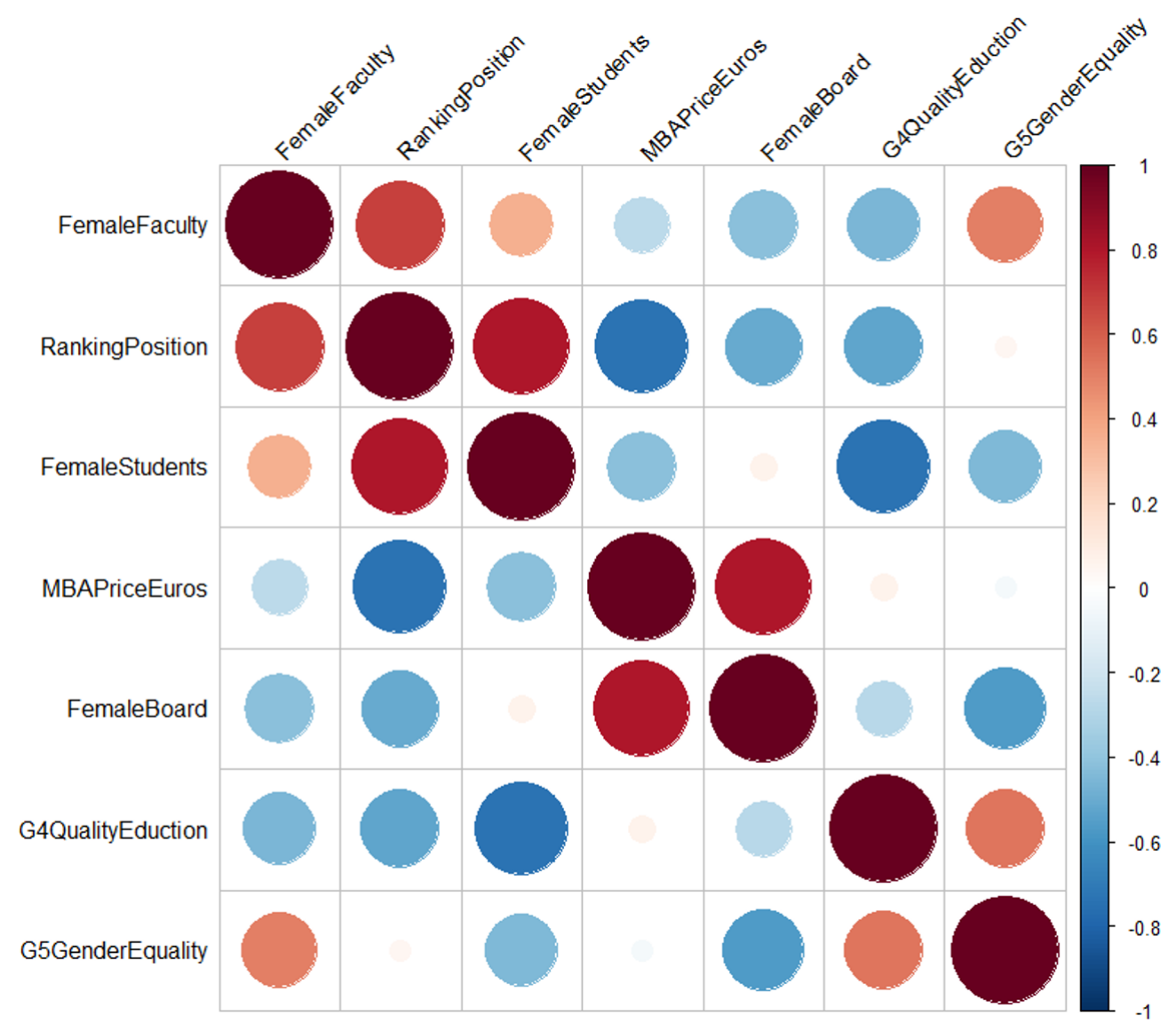

Figure 6. Results and correlations in Asian business schools.

The Asian BS which highlight projects related to gender equality in their SR are also focused on explaining their efforts to provide financial aids to access to their programmes. These schools are the one with a better gender balance in their faculty. Nevertheless, these schools are not the best ranked nor the ones with more women in the classrooms nor in their management boards. 
Efforts in communicating scholarships and awards are not positively linked with female presence in the MBA classrooms. Asian women consider business education as extremely valuable for their professional and personal progress, Chinese and Indian female candidates say that they could pay any price to access to a top-ranked BS, so financial accessibility is not a main concern for them [1]. Top Asian BS should not stress financial aids as key argument to attract women and improve their reputation and legitimacy, because funds access is not a barrier for their female target.

The lack of women in the Asian BS management could be an obstacle in gender balance in classrooms and, therefore, in the female representation in this countries corporate and political leadership $[100,103,109]$. Asian BS could use their SR to highlight, for example, female alumni success stories in the economic and political regional and global development as a source for inspiration for female candidates. This narrative would inspire Asian women to train themselves in the best local BS to cover future leadership positions and improve the schools' reputation and legitimation.

Ranking positioning of Asian BS is positively linked to female faculty and students' percentage. The most expensive schools are the ones with the higher number of women in the management team, that means that elite Asian institutions are aware of the importance to have diversity in their leadership.

\section{Conclusions and Future Research}

Business schools from all around the world use sustainability reports to engage a conversation with their stakeholders and acquire legitimacy [25,43-46]. Although, in the higher education industry, reporting social and sustainable strategies and activities is considered very important and necessary, nevertheless the publication of SR is still not so popular yet $[23,41,110]$. Business schools are communicating their social and sustainable projects through different channels online and offline but not always through a proper SR.

All the top 50 BS according to the "Financial Times Global MBA Ranking 2016" communicate their social and sustainable projects, nevertheless, only 30 of them publishes a proper sustainable report.

The overall results of this research show that, aligning with the priorities defined by the "UN 2030 Sustainable Agenda", top business schools make efforts to promote gender equality and, most of them mention, in their SR, projects related to this effort.

Nevertheless, access to business graduate schools is still difficult for the majority of the global female population, due to a shortage of financial aids, salary gap and lack of gender balance in the business schools' faculty and management team.

To cover this imbalance, top business schools are sourcing awards and scholarships to get talented women in their classrooms or organizing clubs and projects to promote female alumni in corporate boards or to finance entrepreneurship ventures [5].

In fact, despite all these obstacles, an MBA is often considered by women a very important tipping point for their career $[1,4,98]$ and business schools are responsible to promote a more relevant role of women in the global economic and political power [1].

European institutions stress women professional development as a key topic in their communication strategy more than the US and Asian schools. Nevertheless, considering the existing gender gap in the business administration, this topic should be a priority in the business schools communication strategies, especially in their sustainability reports.

Top business schools should consider more carefully the great positive impact they could produce and receive from communicating their policies and projects related to gender equality.

Disclosing their efforts to solve gender imbalance, BS could increase candidates' quality, get a wider diversity in knowledge, a better skills cross-learning in the classrooms, improve teaching and research outputs thank to a wider faculty recruitment base and provide schools' management with a broader and more innovative perspective, incorporating more women into the executive boards.

Despite the fact that the most important ranking of the industry credits only the $5 \%$ of the weight to gender related criteria, we consider that their simple existence is a sign of changes and a beginning 
of a new trend for BS reputation and legitimacy. Alumni salary and economic wealth is not the only criteria to rank the best BS of the world.

According to SDG 4 and 5, working for promoting women' access to power in every corner of the world, through high quality education, financial aids and diversity in management style is a great opportunity for global development. BS have to grab this opportunity, act as game-changers and use this effort to improve their worldwide legitimacy to operate.

In order to analyse the ongoing gender equality agenda in the best BS communication and legitimacy strategy, in future we will perform the same research every five years to compare the obtained results. Besides that, we will compare the opinions of experts with the actual women perception, interviewing female candidates, students, alumni, schools' managers and corporate representatives.

We will also perform netnographic research about the social network sentiment against gender equality business schools related communications and messages, in order to understand the level of acceptance and legitimacy of these strategies and policies by the public opinion in social networks.

Author Contributions: Conceptualization, G.M.; methodology, G.M. and J.R.R.; software, G.M.; data validation, M.P.L.; writing—original draft preparation, G.M.; writing—review and editing, G.M., M.P.L. and J.R.R; visualization, G.M and J.R.R.

Funding: This research received no external funding.

Conflicts of Interest: The authors declare no conflict of interest.

\section{References}

1. Graduate Management Admission Council. What Women Want: A Blueprint for Change in Business Education; Graduate Management Admission Council: Reston, VA, USA, 2017.

2. Schwab, K.; Smans, R.; Zahidi, S.; Leopold, T.A.; Ratcheva, V.; Haussman, R.; Tyson, L.D. Insight Report: The Global Gender Gap Report 2017; World Economic Forum: Cologny/Geneva, Switzerland, 2017.

3. UN Global Compact. UN Sustainable Development Goals. Available online: https:/ /www.unglobalcompact. org/what-is-gc/our-work/sustainable-development/sdgs/17-global-goals (accessed on 1 January 2016).

4. Nilsson, P. The MBA Gender Pay Gap-Readers' Stories. Financial Times, 4 April 2018.

5. Leatherby, L. The Business Schools Women Want to Attend. Financial Times, 22 January 2018.

6. Porter, M.E.; Kramer, M.R. Strategy \& Society: The Link between Competitive Advantage and Corporate Social Responsibility. Harv. Bus. Rev. 2006, 84, 78-92. [PubMed]

7. Crane, A.; Matten, D.; Spence, L.J. Corporate Social Responsability; Routledge: New York, NY, USA, 2008.

8. Kotler, P.; Kartajaya, H.; Setiewan, I. Marketing 3.0; John Wiley and Sons, Inc.: Hoboken, NJ, USA, 2010.

9. Patriotta, G.; Gond, J.P.; Schultz, F. Maintaining Legitimacy: Controversies, Orders of Worth, and Public Justifications. J. Manag. Stud. 2011, 48, 1804-1836. [CrossRef]

10. Ashforth, B.E.; Gibbs, B.W. The Double-Edge of Organizational Legitimation. Organ. Sci. 1990, 1, $177-194$. [CrossRef]

11. Scherer, A.G.; Palazzo, G.; Seidl, D. Managing Legitimacy in Complex and Heterogeneous Environments: Sustainable Development in a Globalized World. J. Manag. Stud. 2013, 50, 259-284. [CrossRef]

12. Khurana, R.; Nohria, N. It's Time to Make Management a True PROFESSION. Harv. Bus. Rev. 2008, 86, 70-77. [PubMed]

13. Deephouse, D.; Carter, S. An Examination of Differences between Organizational Legitimacy and Organizational Reputation. J. Manag. Stud. 2005, 6, 3-23. [CrossRef]

14. Alajoutsijarvi, K.; Juusola, K.; Siltaoja, M. The Legitimacy Paradox of Business Schools: Losing by Gaining? Acad. Manag. Learn. Educ. 2015, 14, 277-291. [CrossRef]

15. Filatotchev, I.; Nakajima, C. Corporate Governance, Responsible Managerial Behavior, and Corporate Social Responsibility: Organizational Efficiency versus Organizational Legitimacy? Acad. Manag. Perspect. 2014, 28, 289-306. [CrossRef]

16. Miotto, G.; Blanco González, A.; Del Castillo Feito, C. Social Responsibility: A Tool for Legitimation in Spanish Universities' Strategic Plans. Trípodos 2018, 42, 59-79. 
17. Suchman, M.C. Managing Legitimacy: Strategic and Institutional Approaches. Acad. Manag. Acad. Manag. Rev. 1995, 20, 571-610. [CrossRef]

18. Meyer, J.W.; Rowan, B. Institutionalized Organizations: Formal Structure as Myth and Ceremony. Am. J. Sociol. 1977, 83, 340-363. [CrossRef]

19. Baumann-Pauly, D.; Scherer, A.G.; Palazzo, G. Managing Institutional Complexity: A Longitudinal Study of Legitimacy Strategies at a Sportswear Brand Company. J. Bus. Ethics 2016, 137, 31-51. [CrossRef]

20. Tata, J.; Prasad, S. CSR Communication: An Impression Management Perspective. J. Bus. Ethics 2015, 132, 765-778. [CrossRef]

21. Brønn, P.S.; Vrioni, A.B. Corporate Social Responsibility and Cause-Related Marketing: An Overview. Int. J. Advert. 2001, 20, 207-222. [CrossRef]

22. Salvioni, D.M.; Franzoni, S.; Cassano, R. Sustainability in the Higher Education System: An Opportunity to Improve Quality and Image. Sustainability 2017, 9, 914. [CrossRef]

23. Alonso-Almeida, M.D.M.; Marimon, F.; Casani, F.; Rodriguez-Pomeda, J. Diffusion of Sustainability Reporting in Universities: Current Situation and Future Perspectives. J. Clean. Prod. 2015, 106, 144-154. [CrossRef]

24. Lozano, R.; Lozano, F.J.; Mulder, K.; Huisingh, D.; Waas, T. Advancing Higher Education for Sustainable Development: International Insights and Critical Reflections. J. Clean. Prod. 2013, 48, 3-9. [CrossRef]

25. Castelló, I.; Lozano, J.M. Searching for New Forms of Legitimacy through Corporate Responsibility Rhetoric. J. Bus. Ethics 2011, 100, 11-29. [CrossRef]

26. Waddock, S.; Lozano, J.M. Developing More Holistic Management Education: Lessons Learned from Two Programs. Acad. Manag. Learn. Educ. 2013, 12, 265-284. [CrossRef]

27. Miotto, G.; Rom, J. CSR in Business Schools: A Theoretical Framework. In Proceedings of the ICERI2017 Proceeding, Sevilla, Spain, 16-18 November 2017; pp. 1410-1419.

28. Ghoshal, S. Bad Managment Theories Are Destroying Good Managment Practices. Acad. Manag. Learn. Educ. 2005, 4, 75-91. [CrossRef]

29. Huehn, M.P. Ethics as a Catalyst for Change in Business Education? J. Manag. Dev. 2016, 35, 170-189. [CrossRef]

30. Losada, C.; Martell Sotomayor, J.; Lozano, J.M. Responsible Business Education: Not a Question of Curriculum but a Raison D'être for Business Schools. In Business Schools and Their Contribution to Society; Morsing, M., Sauquet Rovira, A., Eds.; SAGE Publications Ltd.: Charlotte, NC, USA, 2011.

31. Khurana, R. From Higher Aims to Hired Hands: The Social Transformation of American Business Schools and the Unfulfilled Promise of Management as a Profession; Princeton University Press: Princeton, NJ, USA, 2007.

32. Setó-Pamies, D.; Domingo-Vernis, M.; Rabassa-Figueras, N. Corporate Social Responsibility in Management Education: Current Status in Spanish Universities. J. Manag. Organ. 2011, 5, 604-620. [CrossRef]

33. Cornelius, N.; Wallace, J.; Tassabehji, R. An Analysis of Corporate Social Responsibility, Corporate Identity and Ethics Teaching in Business Schools. J. Bus. Ethics 2007, 76, 117-135. [CrossRef]

34. Scherer, A.G.; Palazzo, G. The New Political Role of Business in a Globalized World: A Review of a New Perspective on CSR and Its Implications for the Firm, Governance, and Democracy. J. Manag. Stud. 2011, 48, 899-931. [CrossRef]

35. Vollero, A.; Palazzo, M.; Siano, A.; Sardanelli, D. Communicating CSR for Legitimacy: A Comparison between Service and Product Companies. In Proceedings of the 20th Excellence in Services International Conference, Verona, Italy, 7-8 September 2017; pp. 825-833.

36. Palazzo, G.; Scherer, A.G. Corporate Legitimacy as Deliberation: A Communicative Framework. J. Bus. Ethics 2006, 66, 71-88. [CrossRef]

37. Daub, C. Assessing the Quality of Sustainability Reporting: An Alternative Methodological Approach. J. Clean. Prod. 2007, 15, 75-85. [CrossRef]

38. Ceulemans, K.; Molderez, I.; Van Liedekerke, L. Sustainability Reporting in Higher Education: A Comprehensive Review of the Recent Literature and Paths for Further Research. J. Clean. Prod. 2015, 106, 127-143. [CrossRef]

39. Fonseca, A.; Macdonald, A.; Dandy, E.; Valenti, P. The State of Sustainability Reporting at Canadian Universities. Int. J. Sustain. High. Educ. 2011, 12, 22-40. [CrossRef]

40. Global Reporting Initiative-GRI. Available online: https://www.globalreporting.org/Information/aboutgri/Pages/default.aspx (accessed on 14 July 2016). 
41. Ceulemans, K.; Lozano, R.; del Mar Alonso-Almeida, M. Sustainability Reporting in Higher Education: Interconnecting the Reporting Process and Organisational Change Management for Sustainability. Sustainability 2015, 7, 8881-8903. [CrossRef]

42. Dyllick, T. Responsible Management Education for a Sustainable World. The Challenges for Business Schools. J. Manag. Dev. 2015, 34, 16-33. [CrossRef]

43. World Business Council for Sustainable Development. World Business Council for Sustainable Development. Available online: http:/ / www.wbcsd.org/about/organization.aspx (accessed on 9 August 2016).

44. Deegan, C. Organisational Legitimacy as a Motive for Sustainability Reporting. In Sustainability Accounting and Accountability; Unerman, J., Bebbington, J., O’Dwyer, B., Eds.; Routledge: London, UK, 2007; pp. 127-149.

45. Thomas, T.E.; Lamm, E. Legitimacy and Organizational Sustainability. J. Bus. Ethics 2012, 110, $191-203$. [CrossRef]

46. Brennan, N.M.; Merkl-Davies, D.M. Rhetoric and Argument in Social and Environmental Reporting: The Dirty Laundry Case. Account. Audit. Account. J. 2014, 27, 602-633. [CrossRef]

47. Lukman, R.; Krajnc, D.; Glavič, P. University Ranking Using Research, Educational and Environmental Indicators. J. Clean. Prod. 2010, 18, 619-628. [CrossRef]

48. Godemann, J.; Haertle, J.; Herzig, C.; Moon, J. United Nations Supported Principles for Responsible Management Education: Purpose, Progress and Prospects. J. Clean. Prod. 2014, 62, 16-23. [CrossRef]

49. The EFMD Accreditation for International Business Schools. 2018 EQUIS Standards \& Criteria; The EFMD Accreditation for International Business Schools: Brussels, Belgium, 2018.

50. The Association to Advance Collegiate Schools of Business (AACSB). Eligibility Procedures and Accreditation Standards for Business Accreditation; AACSB: Tampa, FL, USA, 2018; p. 52.

51. Albrecht, P.; Burandt, S.; Schaltegger, S. Do Sustainability Projects Stimulate Organizational Learning in Universities? Int. J. Sustain. High. Educ. 2007, 8, 403-415. [CrossRef]

52. Davis, G.; Searcy, C. A Review of Canadian Corporate Sustainable Development Reports. J. Glob. Responsib. 2010, 1, 316-329. [CrossRef]

53. King, A.; Bartels, W. Currents of Change. The KPMG Survey of Corporate Responsibility Reporting 2015; KPMG International Cooperative: Amstelveen, The Netherlands, 2015.

54. Kolk, A. Trends in Sustainability Reporting by the Forturne Global 250. Bus. Strateg. Environ. 2003, 12, $279-291$. [CrossRef]

55. Kolk, A. Trayectories of Sustainability Reporting by MNCs. J. World Bus. 2010, 45, 367-374. [CrossRef]

56. Beloe, S.; Elkington, J.; Hester, K.F.; Loose, M.; Zollinger, P. Tomorrow's Value: The Global Reporters 2006 Survey of Corporate Sustainability Reporting; SustainAbility: London, UK, 2006.

57. Perez, F.; Sanchez, L.E. Assessing the Evolution of Sustainability Reporting in the Mining Sector. Environ. Manag. 2009, 43, 949-961. [CrossRef] [PubMed]

58. Roca, L.C.; Searcy, C. An Analysis of Indicators Disclosed in Corporate Sustainability Reports. J. Clean. Prod. 2012, 20, 103-118. [CrossRef]

59. Kozlowski, A.; Searcy, C.; Bardecki, M. Corporate Sustainability Reporting in the Apparel Industry. Int. J. Product. Perform. Manag. 2015, 64, 377-397. [CrossRef]

60. Hartman, L.P.; Rubin, R.S.; Dhanda, K.K. The Communication of Corporate Social Responsibility: United States and European Union Multinational Corporations. J. Bus. Ethics 2007, 74, 373-389. [CrossRef]

61. Islam, M.A.; Deegan, C. Media Pressures and Corporate Disclosure of Social Responsibility Performance Information: A Study of Two Global Clothing and Sports Retail Companies. Account. Bus. Res. 2010, 40, 131-148. [CrossRef]

62. Escudero, M. PRME and Four Theses on the Future of Management Education. In Business Schools and Their Contribution to Society; Morsing, M., Sauquet Rovira, A., Eds.; SAGE Publications Ltd.: Thousand Oaks, CA, USA, 2011; pp. 201-212.

63. Miotto, G. LEGITIMACY AND BUSINESS SCHOOLS: Analysis of the Business Schools' Social and Sustainability Reports According with United Nations Sustainable Development Goals. Ph.D. Thesis, Ramon Llull University (URL), Barcelona, Spain, 2017.

64. Brown, J.A.; Clark, C.; Buono, A.F. The United Nations Global Compact: Engaging Implicit and Explicit CSR for Global Governance. J. Bus. Ethics 2018, 147, 721-734. [CrossRef]

65. Pettigrew, A.; Starkey, K. The Legitimacy and Impact of Business Schools: Key Issues and a Research Agenda. Acad. Manag. Learn. Educ. 2016, 15, 649-664. [CrossRef] 
66. Figueiró, P.S.; Raufflet, E. Sustainability in Higher Education: A Systematic Review with Focus on Management Education. J. Clean. Prod. 2015, 106, 22-33. [CrossRef]

67. Perry, M.; Win, S. An Evaluation of PRME's Contribution to Responsibility in Higher Education. J. Corp. Citizsh. 2013, 49, 48-70. [CrossRef]

68. Arbaugh, J.B.; Bento, R.; Hwang, A. Does the MBA Experience Support Diversity? Demographic Effects on Program Satisfaction. Decis. Sci. J. Innov. Educ. 2010, 8, 391-415. [CrossRef]

69. Bruggeman, P.; Chan, H. Minding the Gap: Tapping the Potential of Women to Transform Business; Graduate Management Admission Council: Reston, VA, USA, 2016.

70. Barrett, P.; Nilsson, H. Top MBAs for Women. Financial Times, 5 March 2018.

71. Cocchiara, F.K.; Kwesiga, E.; Bell, M.P.; Baruch, Y. Influences on Perceived Career Success: Findings from US Graduate Business Degree Alumni. Career Dev. Int. 2010, 15, 39-58. [CrossRef]

72. Zarya, V. The Share of Female CEOs in the Fortune 500 Dropped by 25\% in 2018. Fortune, 21 May 2018.

73. Noyes, K. For Women MBA Students, It's Getting Better. Fortune, 13 October 2014.

74. Hemphill, L. Why Women Should Skip Business Schools. The New Yorker, 16 September 2013.

75. Kelan, E.K.; Dunkley Jones, R. Gender and the MBA. Acad. Manag. Learn. Educ. 2010, 9, $26-43$.

76. Ituma, A. Gender, Feminization and the MBA: A Review of the Contribution of Ruth Simpson. Gend. Manag. 2017, 32, 461-467. [CrossRef]

77. Simpson, R. Masculinity and Management Education: Feminizing the MBA. Acad. Manag. Learn. Educ. 2006, 5, 182-193. [CrossRef]

78. Carmona, S.; Ezzamel, M.; Mogotocoro, C. Gender, Management Styles, and Forms of Capital. J. Bus. Ethics 2018, 153, 357-373. [CrossRef]

79. Searcy, C.; Buslovich, R. Corporate Perspectives on the Development and Use of Sustainability Reports. J. Bus. Ethics 2014, 121, 149-169. [CrossRef]

80. Guijarro, F.; Poyatos, J.A. Designing a Sustainable Development Goal Index through a Goal Programming Model: The Case of EU-28 Countries. Sustainability 2018, 10, 3167. [CrossRef]

81. Keitsch, M. Structuring Ethical Interpretations of the Sustainable Development Goals-Concepts, Implications and Progress. Sustainability 2018, 10, 829. [CrossRef]

82. Wilson, D.C.; Thomas, H. The Legitimacy of the Business of Business Schools: What's the Future? J. Manag. Dev. 2012, 31, 368-376. [CrossRef]

83. Mårtensson, P.; Richtnér, A. What Parameters Do Students Value in Business School Rankings? J. High. Educ. Policy Manag. 2015, 37, 646-658. [CrossRef]

84. Sauder, M.; Espeland, W.N. The Discipline of Rankings: Tight Coupling and Organizational Change. Am. Sociol. Rev. 2009, 74, 63-82. [CrossRef]

85. Snelson-Powell, A.; Grosvold, J.; Millington, A. Business School Legitimacy and the Challenge of Sustainability: A Fuzzy Set Analysis of Institutional Decoupling. Acad. Manag. Learn. Educ. 2016, 15, 703-723. [CrossRef]

86. Wedlin, L. Going Global: Rankings as Rhetorical Devices to Construct an International Field of Management Education. Manag. Learn. 2011, 42, 199-218. [CrossRef]

87. Gioia, D.A.; Corley, K.G. Being Good versus Looking Good: Business School Rankings and the Circean Transformation from Substance to Image. Acad. Manag. Learn. Educ. 2002, 1, 107-120. [CrossRef]

88. Christensen, L.J.; Peirce, E.; Hartman, L.P.; Hoffman, W.M.; Carrier, J. Ethics, CSR, and Sustainability Education in the Financial Times Top 50 Global Business Schools: Baseline Data and Future Research Directions. J. Bus. Ethics 2007, 73, 347-368. [CrossRef]

89. Abela, J.A.; García-Nieto, A.; Pérez Corbacho, A.M. Evolución de La Teoría Fundamentada Como Técnica de Análisis Cualitativo; Cuadernos Metodológicos: Madrid, Spain, 2007.

90. Silver, C.; Lewins, A. Using Software in Qualitative Research a Step by Step Guide; SAGE Publications Ltd.: London, UK, 2014.

91. Trinidad Requena, A.; Carrero Planes, V.; Soriano Miras, R.M. Teoría Fundamentada «Grounded Theory». La Construcción de La Teoría a Través Del Análisis Interpretacional; Cuadernos Metodológicos: Madrid, Spain, 2006.

92. Valles, M.S. Ventajas y Desafíos Del Uso de Programas Informáticos (e.g.ATLAS.Ti y MAXqda) En El Análisis Cualitativo. Una Reflexión Metodológica Desde La Grounded Theory y El Contexto de La Investigación Social Española. Dep. Metodol. la Investig. da Univ. Comlutense Madrid 2001, No. Mcc, 1-26.

93. Piñuel Raigada, J.L. Epistemología, Metodología y Técnicas Del Análisis de Contenido. Estud. Sociolinguística 2002, 3, 1-42. 
94. Muñoz Justicia, J. Análisis Cualitativo de Datos Textuales Con ATLAS.Ti 5; Universitat Autònoma de Barcelona: Barcelona, Spain, 2005.

95. Friese, S. Using ATLAS.Ti for Analyzing the Financial Crisis Data 1. Introduction and Underlying Assumptions. Forum Qual. Soc. Res. 2011, 12, 1-24.

96. Olabuénaga, J.I.R. Metodología de La Investigación, 5a; Universidad de Deusto: Bilbao, Spain, 2012.

97. General Assembly of United Nations. Transforming Our World: The 2030 Agenda for Sustainable Development. In Resolution Adopted by the General Assembly on 25 September 2015; General Assembly of United Nations: New York, NY, USA, 2015.

98. Ortmans, L. MBA by Numbers: The Gender Salary Divide. Financial Times, 17 April 2015.

99. Financial Times. Finacial Times Global MBA Ranking 2016. Financial Times, 26 January 2016.

100. Morley, L.; Crossouard, B. Women's Leadership in the Asian Century: Does Expansion Mean Inclusion? Stud. High. Educ. 2016, 41, 801-814. [CrossRef]

101. Lehmann, E.L. Nonparametrics: Statistical Methods Based on Ranks; Springer: New York, NY, USA, 2006.

102. Cohen, J.; Cohen, P.; West, S.G.; Aiken, L.S. Applied Multiple Regression. Correlation Analysis for the Behavioral Sciences; Routledge: Abingdon, UK, 2013.

103. Mok, K.H. Does Internationalisation of Higher Education Still Matter? Critical Reflections on Student Learning, Graduate Employment and Faculty Development in Asia. High. Educ. Q. 2018, 72, 183-193. [CrossRef]

104. Commission for Justice Consumers and Gender Equality. 2018 Report on Equality between Women and Men in the European Union; Commission for Justice Consumers and Gender Equality: Brussels, Belgium, 2018.

105. Windscheid, L.; Bowes-Sperry, L.; Jonsen, K.; Morner, M. Managing Organizational Gender Diversity Images: A Content Analysis of German Corporate Websites. J. Bus. Ethics 2018, 152, 997-1013. [CrossRef]

106. Cornuel, E.; Hommel, U. Moving beyond the Rhetoric of Responsible Management Education. J. Manag. Dev. 2015, 34, 2-15. [CrossRef]

107. Lozano, J.M.; Bofarull, I.; Waddock, S.; Prat-i-Pubill, Q. Avoiding the Iron Cage of Business School Rankings. High. Educ. Policy 2018, 1-23. [CrossRef]

108. Financial Times. Financial Times: Business Schools Rankings. Available online: http://rankings.ft.com/ businessschoolrankings/rankings (accessed on 5 May 2016).

109. Collet, F.; Vives, L. From Preeminence to Prominence: The Fall of U.S. Business Schools and the Rise of European and Asian Business Schools in the Financial Times Global MBA Rankings. Acad. Manag. Learn. Educ. 2013, 12, 540-563. [CrossRef]

110. Lozano, R. The State of Sustainability Reporting in Universities. Int. J. Sustain. High. Educ. 2011, 12, 67-78. [CrossRef]

(C) 2019 by the authors. Licensee MDPI, Basel, Switzerland. This article is an open access article distributed under the terms and conditions of the Creative Commons Attribution (CC BY) license (http://creativecommons.org/licenses/by/4.0/). 